Saeed Safari, PhD*

Faculty of Philology

University of Belgrade
$02(55)$

https://doi.org/10.18485/melissa.2018.17.1.ch4

Оригинални научни рад

Примљен: 11.08.2018

Прихваћен: 11.09.2018.

\title{
IRANIAN LIBRARIES ALONG THE SILK ROAD
}

\begin{abstract}
Summary
Iran as a homeland for ancient civilizations has a long tradition in preserving the written works and the history of writing in the Persian Empire dates back to four thousand years ago. Library and librarianship in Iran has developed through the history, based on documents, in Achaemenid Empire, the Apadana Palace Library contained thousands of Clay tablet, used as a writing medium, which could indicate the old tradition of Iranian librarianship. The most well-known library of the ancient Persia belonged to the Academy of Gondishapur, also known as the Jondishapur University, in the era of Sasanian Empire. After Islam, libraries were based in the islamic schools, such as Nezamiyeh, Madrese, Beyt Al-hekme, etc. Most of those libraries where located in cities which were the main route of the Silk Road. In this paper, a classification of three historical period of Iranian libraries, before Islam, after Islam and in Modern era, are introduced.
\end{abstract}

Key words: The Silk Road, Persian Empire, Iranian libraries, Academy of Gondishapur.

\section{Introduction}

The keeping of recorded knowledge and collecting books has a long tradition and even an ancient history in Iran. Around twenty- five centuries ago, Darius the Great (522-486 B.C.) placed his trilingual inscription on the face of Bisotun Mountain in the northwest of Iran which still reserved. This is an evident that ancient manuscripts are reserved and so it indicate to a long tradition of keeping information and developing written inscriptions. During the history, lots of collections of books and libraries

Faculty of Philology, Studentski trg 1, 11000, Belgrade

saeed.safari@fil.bg.ac.rs 
were build up and destroyed in battles and invasions. In this paper, in order to review the background of Iranian libraries, three historical background will be introduced.

The Silk Road was generally known as a trade route between the Mediterranean Sea and China however it was a term for a set of routs which connects the most eastern countries to the rest of the world. In this trading rout, not only silk, but many goods were transited from China and the far reaches of Asia, to Central Asia, North Africa and Central Europe. This route did not only promote goods and commodities exchange but also cultural, art and religion. Libraries on the Silk Road, as the treasury of knowledge, had the significant role in such cultural exchange. Generally, libraries were of three types: a) imperial, b) religious and c) private. Imperial collections were kept in the royal court, religious libararies were in mosques and private libraries belonged to the scholars.

\section{Ancient Iranian Libraries}

Ancient Iranian libraries were mainly Royal libraries or libraries of princes and ministers which most of them were destroyed during three great invasions by Greeks (333 B.C.), Arabs (641) and Mongols (1220). By ancient libraries, we mean the libraries before Arab invasion, i.e before starting the Islamic period in the Iranian history and only 2 significant libraries which were on the silk road are introduced:

According to Ibn Nadim, there were in Apadana Palace at Persepolis inscriptions on wooden, stone and clay tablets which covered various subjects. Most of them were destroyed by Alexander of Macedonia or sent by him to the Alexandria Library. In 1934 in the basement of the ruined Apadana Palce, 30,000 clay tablets were discover and archeologists have called this place the Treasure of Persepolis of Estakhr Library ((Kent et al, 1975). In Sasanid period (225-651 A.D) a big library establish by Xosro the first in Gondishapur for the Academy. The academy was the most well-known center during the Sasanid time. According to documents, may scholars of various nationalities were gathered there and many books were translated into Persian (ibid).

The Academy of Gondishapur, also known as The Gondishapur University, was one of the three Sasanian centers of education (Ctesiphon, 
Resaina, Gundeshapur) and academy of learning in the city of Gundeshapur, Iran during late antiquity, the intellectual center of the Sasanian Empire.Gondishapur, which used to a city in south west of Iran, is located in $14 \mathrm{~km}$ south-east of Dezful, to the road for Shushtar, in the presentday province of Khuzestan. The city was famous as the intellectual centre of the Sassanid Empire and the home of the Academy of Gundishapur, founded by Sassanid king Shapur I. Gundeshapur was home to a teaching hospital and had a library and a centre of higher learning.

The Academy of Gondishapur offered education and training in medicine, philosophy, theology and science. The faculty was versed in Persian traditions. According to The Cambridge History of Iran, it was the most important medical center of the ancient world during the 6th and 7th centuries (Frye, 1975).

Monzavi (2013) also mentioned that "The ninth king of the Sassanid Empire, Shapour II, chose the city as his capital and built the world's oldest known medical center, which also included a university and a library with an estimated 400,000 books. Later in the Islamic period, the library again revived and due to its rich collections of Hebrew, Greco-Hellenistic, Syriac, and Zorostarin philosophical, religious and scientific works were translated and even transited to the entire Muslim world. By the middle of $13^{\text {th }}$ century they had also been translated into Latin and other European languages (Purhadi, 1958). In addition to these libraries, it is believed that other libraries were in fire-temples and places of worship as well as hospitals.

\section{Iranian Libraries in the Islamic Period}

The Islamic conquest of Persia (637-651) led to the end of the Sasanian Empire and the eventual decline of the Zoroastrian religion in Persia. However, the achievements of the previous Persian civilizations were not lost, but were to a great extent absorbed by the new Islamic polity and laws. The Arabs tried to eradicate all that was non-Quranic. The invaders believed that the content of a book might agree with the Koran, but could not be superior to it, so generally non-Qoranic books deserved to be annihilated, therefore, the Iranian libraries were destroyed and books were 
burned (Zarinkub, 1957). Later, gradually as the political situation permitted, libraries were assembled. The libraries in Iran at this period were very well organized, for every branch of knowledge there was a separate section. Some libraries even supplied food, lodging and other faculties for the convenience of scholars who had come from distant land to do research (Purhadi, 1958)

In the eleventh and twelfth centuries, libraries were numerous and there was a flourishing book trade. In this period, libraries were established in seminary (schools of theology, dar-alhekme. Beyt alhekme- nezamiyeh, madrese, maktab etc), mosques and there were private libraries as well. Some cities, along the Silk Road, which were famous for having libraries are Nishapur, and Merve (the great Xorasan) Isfahan, Shiraz and Rey. As an example, let's take a look at libraries in Nishapur. Nishapur which is today located in northeastern Iran is a city in Razavi Khorasan Province, capital of the Nishapur County and former capital of Province Khorasan. It seems to have been founded by the Sasanian Shapur I in the 3rd century $\mathrm{CE}$, and possibly rebuilt by Shapur II in the following centuries. The city, located on the Silk Road, was one of the main cities with big libraries during middle ages. Since there were lots of scholars who lived in this city to study or to teach in schools and madresa, big libraries were established, such as Al-Sapuni library and Dar-Slaste, Nezamiyeh, Mohamd Al-Qazali private library, Alshajari library, Abi-Said libarey, Aqil Mosque libarary with about 5 thousands books and Beyhaqi School library (Wikipedia, n.d). In Shiraz, which is now the capital of Fars province in middle of Iran, the Shiraz foundation was built by the Buyyid prince, Azud Al-Daula (d. 982) on his palace grounds. The library, which contained much scientific literarure, was in the charge of a director (Wakil), a libareian (Hazen), and a superinterndent. The books were stored in a long, arched hall with stack room on all sides and each branch of knowledge had separate bookcases and catalogs (Kent et al, 1975). It should be mention that many large libraries were founded in the Safavid Period (1510-1736). The Royal library in Isfahan was the greatest one. In that period, there was even a big library in Jolfa, near Isfahan, for the Armanian refuges which had works on Christianity.

In Mashhad, a city in north east of Iran, where the holey shrine of Imam Reza, the $8^{\text {th }}$ imam of Shiites is located there, a great library was 
established in a part of this holy shrine in $14^{\text {th }}$ century (around 700 years), which exists to the present. This well-known and library is called the library of Astan-e Qods-e Razai which is the oldest existing library in Iran. The collections of this library are mainly manuscripts.

\section{Iranian Libraries in the Modern Era}

The modern era of the Iranian libraries and librarianship dates back to 1960 , however, the idea of creating the public libraries which would meet everybody's needs developed at the threshold of the constitutional revolution (1906). A group of liberalists and patriots installed a small library in Tehran, some year later its collection transferred to the Dar-AlFonun college and there was thus established the Public Library of Education or 1921. (Ebrahimi, 1974)

The National Library of Iran, which is located in Tehran and is the largest library in the country was officially opened in 1937. However, the first portoype of a national library in Iran was the library of Dar-Al-Fonun College, established in 1851 (Murray, 2009). The national library building is specially designed to combine different faculties of the library in a single platform. The library by itself is over $90,000 \mathrm{~m}^{2}$, the largest library campus in the Middle East. It encompasses 5 separate halls, each hall dedicated to a different faculty, including Humanities, Social Sciences, Law, Science and Science Education, and Health Studies.

Public libraries are developed later after the revolution in 1975 and today according to statistics over 3400 libraries are active for services. Academic libraries which are mainly based at universities, school and mosque libraries and religious libraries and private libaries are developed in recent decades in all cities, and the ones used to be on the old Silk Road.

\section{Conclusion}

Iran as one of the largest countries in the Middle East used to be a major trading route on the Silk Road. Although Libraries and librarianship has a long tradition in Iran, the cities which were on the Silk Road in 
Iran had biggest and oldest libraries which indicate the importance of the cultural transition in that route and imply this note that the Silk Road was not only a trade route, but also a highway for flowing of knowledge and information.

\section{References}

Ebrami, H. (1974). Libraries in Iran, in Allen Ken et al. (eds). Encyclopedia of Library and Information Sience, New York: .Marcel Dekker, Vol. 13, pp. 15--53.

Frye, R. (Ed.). (1975). The Cambridge History of Iran (The Cambridge History of Iran). Cambridge: Cambridge University Press.

Hidar, S.J (1974). Public Libraries in Iran. UNESCO Bulletin for Libraries.P 300.

History of Iranian libraries (n.d.). In Wikipedia. Retrieved March 07,

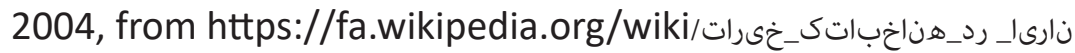

Kent, A., Lancour, H., \& Daily, J.H. (1975). Encyclopedia of Library and Information Science: Volume 13, Marcel Dekker, New York.

Murray, S. (2009). The librar : an illustrated history / Stuart A.P. Murra ; introduction by Donald G. Davis, Jr. foreword by Nicholas A. Basbanes. New York

Pourhadi, I. (1958). Iran's Public and Private Libraries, The Quarterly Journal of the Library of Congress. Vol. 25, No. 3 (JULY 1968), pp. 218-229.

Zarinkub, G.H (1957). Two Centuries of Silence: An Account of Events and Conditions in Iran During the First Two Hundred Years of Islam, from the Arab Invasion to the Rise of the Tahirid Dynasty, Amirkabir Publication, Iran. 


\section{Саид Сафари}

\section{ИРАНСКЕ БИБЛИОТЕКЕ ДУЖ ПУТА СВИЛЕ}

\section{Сажетак}

Иран као домовина древних цивилизација има дугу традицију у очувању писаних дела, а историја писања у Персијском царству датира још пре четири хиљаде година. Библиотека и библиотекарство у Ирану се развијало кроз историју, на основу докумената у Ахеменидском царству, библиотека палате Ападана садржи хиљаде глинених таблица, које су коришћене као медиј за писање, што би могло указати на стару традицију иранског библиотекарства. Најпознатија библиотека древне Персије припала је Академији Гондишапура, познатој и као Универзитет Јундисхапур, у ери Сасанидског царства. Након ислама, библиотеке су биле у исламским школама. Већина ових библиотека налази се у градовима који су били главна рута пута свиле. У овом раду уведена је класификација три историјска периода иранских библиотека, период пре ислама, након ислама и модерна ера.

Кључне речи: Пут свиле, Персијско царство, иранске библиотеке, Академија Гондишапура. 